\title{
Identidade e representação: análise fílmica da mulher em A Fita Branca
}

\author{
Sabrina Martins \\ Mestranda; Universidade Feevale \\ sabrina@feevale.br \\ Cleber Prodanov \\ Doutor; Universidade Feevale \\ prodanov@feevale.br
}

\section{Resumo}

O presente artigo analisa as representações femininas existentes no filme alemão A Fita Branca (2009) e a forma como estas representações constituem a identidade das mulheres na obra. Por meio da descrição de cenas e sequências do filme e da incorporação dos conceitos de representação, identidade e discurso procura-se demonstrar de que maneira as mulheres são subjugadas, além de toda a rigidez, o patriarcalismo e o puritanismo da sociedade local.

\section{Palavras-chave}

Mulher. Representação. Identidade. Análise fílmica.

\section{Introdução}

A obra fílmica A Fita Branca, foi lançada em 2009, sendo vencedora da Palma de Ouro do Festival de Cannes (2009) e recebendo o Globo de Ouro de melhor filme estrangeiro (2010). A narrativa é situada em um vilarejo no norte da Alemanha, em 1913, pouco tempo antes da Primeira Guerra Mundial. Nesta aldeia, o povoado começa a sofrer com alguns incidentes aparentemente sem solução: a queda do médico, causada por um arame preso entre duas árvores; a morte suspeita de uma camponesa na serraria da fazenda; o sequestro e tortura do filho do Barão e a tortura do filho deficiente da parteira. Esses incidentes, considerados criminosos, abalam a estrutura quase imutável da sociedade da aldeia. 
Sob o tema "Identidade e Representação: a mulher em A Fita Branca", este artigo tem como objetivo analisar a forma como a mulher é representada no filme e a maneira como as representações constituem a identidade das mulheres na obra. Para isso analisam-se cenas que mostram personagens femininas em destaque: a esposa do pastor; Sra. Wagner, a parteira; Anni, a filha do médico; Klara, a filha do pastor e a baronesa - mulheres que têm as suas vidas entrecruzadas na trama que se desenvolve na década de 10 do século XX. Para o estudo das personagens são utilizados os conceitos de representação e de identidade sustentados pelos autores Roger Chartier (1990), Stuart Hall (1999, 2012), Kathryn Woodward (2012) e Tomaz Tadeu da Silva (2012), bem como são analisados os diálogos a partir de teorias do discurso e do silêncio, abordados por Homi Bhabha (1998) e Enni Orlandi (2007). Para isso, analisam-se as principais cenas e diálogos das personagens femininas.

Em diferentes culturas, tempo e espaço, a mulher possui um deslocamento no seu lugar de fala, marcando uma conjuntura histórica de poder e de submissão, que perdura por cada período que se sucede, sob uma nova configuração. Os meios de comunicação e as obras cinematográficas procuram narrar estas histórias a partir da noção de discurso e de uma sequência de enunciados que "desrealizam" a coisa contada, como menciona Gaudreault e Jost (2009). Tendo semelhanças ou não com o contexto histórico do período, a obra permite refletir e discutir sobre a construção da identidade feminina. Será que, de certa forma, encontram-se traços da identidade da mulher de A Fita Branca na sociedade atual?

\section{Identidade, diferença e linguagem}

Os conceitos de identidade e diferença possuem uma relação de estreita dependência, sendo inseparáveis. A identidade é aquilo que se é, uma característica independente, por exemplo, "ser mulher", constituindo-se a partir da negação do outro, da percepção do diferente. Nessa perspectiva, a identidade só tem como referência a si própria, ela é autossuficiente. Conforme Silva (2012), a forma afirmativa como expressamos a nossa identidade tende a parecer que a referência se esgota em si mesma. Entretanto, essa afirmação só é possível porque existe a diferença. Deste modo, o que o outro não é, é o que sou. Assim, diversas afirmações são postas a partir de uma cadeia interminável de negações.

A identidade e a diferença são criadas por meio de atos da linguagem, é por meio da fala que instituímos a identidade e a diferença como tais. "Elas têm que ser ativamente produzidas, não são criaturas de um mundo transcendental, mas do mundo cultural e social. 
Somos nós que a fabricamos no contexto das relações culturais e sociais". (SILVA, 2012, p. 76). A língua também não passa de um sistema de diferenças em que o signo só constitui um valor absoluto a partir de uma cadeia de significados que se remete a ele. A isso, Orlandi acrescenta que a identidade não se reduz à identificação: ela mobiliza processos mais complexos. "Um desses processos nos permite apreciar a produção da diferença, justamente pela forma como o silêncio faz parte da relação do sujeito com o sentido". (ORLANDI, 2007, p. 90).

A palavra é um signo e, conforme Bakhtin (2004, p. 16), "Todo o signo é ideológico. [...]. A palavra é o signo ideológico por excelência; ela registra as menores variações das relações sociais". Para ele, "A palavra veicula, de maneira privilegiada, a ideologia; a ideologia é uma superestrutura, as transformações sociais da base refletem-se na ideologia e, portanto, a língua que as veicula". (BAKHTIN, 2004, p. 17). Não é possível prender a palavra em um dicionário, mantê-la como unicidade, porque o signo é, por natureza, vivo e móvel, moldando-se às diversas formas de comunicação, o que implica conflitos e relações de dominação e de resistência. "O discurso é um lugar de significação, de confronto de sentidos, de estabelecimento de identidades, de argumentação, a partir do qual se podem materializar ideologias". (ORLANDI, 2007, p. 19). A classe dominante é quem normalmente tem o interesse de torná-lo monovalente.

Sem os separarmos das amplas relações de poder, pode-se afirmar que o discurso, a palavra e, até mesmo, o silêncio nunca são inocentes, pois constituem uma força homogeneizadora. "As relações de identidade e diferença ordenam-se, todas, em torno de oposições binárias: masculino/feminino [...]. Questionar a identidade e a diferença como relações de poder significa problematizar os binarismos em torno dos quais se organizam". (SILVA, 2012, p. 83). Conforme Silva (2012), o processo de produção da identidade oscila entre dois movimentos: de um lado, estão aqueles processos que tendem a fixar e a estabilizar a identidade; de outro, os processos que tendem a subvertê-la e a desestabilizála. É um processo semelhante ao que acontece com os mecanismos discursivos e linguísticos, a partir dos quais se sustenta a produção da identidade. "A fixação é uma tendência e, ao mesmo tempo, uma impossibilidade". (SILVA, 2012, p. 84).

\section{Identidade e representação}

A representação inclui práticas de significação e sistemas simbólicos por meio dos quais os significados são produzidos, posicionando-nos como sujeitos. É a partir de tais 
significados, produzidos pela representação e pelas atribuições de sentidos, que damos sentido à nossa experiência e àquilo que somos. "Os discursos e os sistemas de representação constroem os lugares a partir dos quais os indivíduos podem se posicionar e a partir dos quais podem falar". (WOODWARD, 2012, p. 17). Conforme Silva (2012), a representação é um sistema linguístico e cultural: arbitrário, indeterminado e estreitamente ligado a relações de poder. Apesar de estabelecerem uma aproximação com a realidade, Chartier (1990) afirma que é necessário esclarecer que as representações sempre são influenciadas pelos interesses dos grupos que as produzem:

As representações do mundo social, assim construídas, embora aspirem à universalidade, de um diagnóstico fundado na razão, são sempre determinadas pelos interesses de grupo que as forjam. Daí, para cada caso, o necessário relacionamento dos discursos proferidos com a posição de quem o utiliza [...]. As percepções do social não são, de forma alguma, discursos neutros: produzem estratégias e práticas que tendem a impor uma autoridade à custa de outros, por elas menosprezados, a legitimar um projeto reformador ou a justificar, para os próprios indivíduos, as suas escolhas e condutas. Por isso, esta investigação sobre as representações supõe-nas como estando sempre colocadas num campo de concorrências e de competições cujos desafios se enunciam em termos de poder e de dominação. (CHARTIER, 1990, p. 17).

É por meio da representação, assim compreendida, que a identidade e a diferença passam a existir. Representar é como afirmar "essa é a identidade", a "identidade é isso". É também por meio da representação que a identidade e a diferença se relacionam aos sistemas de poder, pois todas as práticas de significação que produzem significados consideram o poder de definir quem é incluído e quem é excluído. Os sistemas simbólicos fornecem novas formas de dar sentido à experiência das divisões e das desigualdades sociais, assim como levam em conta os meios pelos quais grupos são estigmatizados. Conforme Silva (2012, p. 91), "Quem tem o poder de representar, tem o poder de definir e determinar a identidade".

[...] a identidade marca o encontro de nosso passado com as relações sociais, culturais e econômicas nas quais vivemos agora [...] a identidade é a intersecção de nossas vidas cotidianas com as relações econômicas e políticas de subordinação e dominação. (RUTHERFORD, $1990^{1}$ apud WOODWARD, 2012, p. 19).

Para Chartier (1990), há uma forma de compreender a apropriação dos discursos, a maneira como estes afetam o sujeito e o conduzem a uma nova compreensão de si próprio e do mundo. $\mathrm{O}$ autor esclarece que os agenciamentos discursivos e as categorias que os

${ }^{1}$ RUTHERFORD, J. Identity: community, culture, difference. London: Lawrence and Wishart, 1990. 
fundam - como os modos de representações - não se reduzem absolutamente às ideias que enunciam, possuem sua lógica própria, que pode ser contraditória em seus efeitos. Dessa maneira, Chartier (1990) elabora a ideia de representação como instrumento capaz de apreender a internalização simbólica das lutas pelo poder e pela dominação, estruturadas a partir de relações externas entre grupos ou indivíduos e que existem independentemente das consciências e das vontades individuais. Há sujeito, há objeto, há representação.

\section{Análise fílmica das cenas}

A partir das noções supracitadas e das operações constantes de inclusão e de exclusão das personagens em um determinado campo social é que se discute a constituição da identidade feminina no filme A Fita Branca. Por meio de certos princípios estéticos, o diretor da obra, Michael Haneke, promove um olhar sobre a mulher inserida em um discurso de domínio cultural, a partir de uma crítica ao pensamento eurocêntrico e aos males que derivam de sua doutrina. Atendendo a diversos interesses estéticos e críticos, Haneke busca nas práticas do teatro o valor de sua autoria e a sua principal ferramenta de estilo ${ }^{2}$, que se mantém, constantemente, em jogo com os mecanismos psicológicos dos espectadores. Os enquadramentos, a incorporação do fora de plano, os sons, as cores, o tempo, os espaços de reflexão e o silêncio são apenas alguns dos recursos estéticos com os quais o diretor trabalha, que se consagraram como suas marcas autorais.

Em uma análise geral da obra, encontra-se no filme uma narração em off conduzida pelo professor da cidade - estratégia narrativa que dá ao espectador informações sobre os estados sucessivos das personagens, em uma referida ordem, considerando um vocabulário escolhido, através do seu ponto de vista, (GAUDREAULT; JOST, 2009). Deste modo, explicitando a independência que a trama assume quando os conhecimentos do narrador definem o que deve ser mostrado. Para Xavier (2003), o ponto de vista no cinema parte do olhar, do espaço, da cena em direção a uma visão de mundo, onde se passa a tomar posição em favor ou contra alguém ou a alguma coisa, um posicionamento interpretativo que permite expandir o olhar sobre determinada obra.

\footnotetext{
${ }^{2}$ Na década de1960 ocorrem grandes mudanças no meio artístico alemão, até então, prejudicado pelos desastres da guerra. Das cinzas do pós-guerra surge uma nova corrente cinematográfica conhecida com o nome de Novo Cinema Alemão, formada por um grupo de jovens diretores, que nasce como resposta a uma necessidade de mudança e de renovação artística na nova Alemanha. Os representantes máximos do movimento e, portanto, predecessores diretos de Michael Haneke são Rainer Werner Fassbinder, Werner Herzog, Wim Wenders e Volker Schlöndorff. Estes são filmes de tendência política onde se analisam as leis pelas quais eram regidas as relações sociais da época, bem como possuem um conceito de teatralidade cinematográfica. A obra de Haneke e seu caráter teatral podem ser considerados uma herança deste movimento, principalmente no que se refere ao aspeto estético-ideológico de suas propostas.
} 
Os numerosos planos-sequência também caracterizam fortemente o filme e tornam o ambiente absolutamente possível, como se o fato de aquele local e pessoas estarem sendo filmadas fosse quase acidental. A câmera trabalha de forma autônoma, como objeto independente. Pela escuridão de muitas cenas pouco se percebe visualmente, mas muito se intui. A câmera passeia pelos cenários revelando, lentamente, o que as personagens enxergam, ou melhor, o que pensam enxergar. Haneke também utiliza uma técnica de entrada e saída das personagens do quadro, no qual o ator entra livremente na cena, para desenvolver a função narrativa (diálogos, ações, etc.), e sai sem se preocupar em deixar o quadro vazio. Ambas as técnicas fortalecem a ideia de teatralidade presente na obra de Haneke, como uma estratégia que gera a impressão de realidade no espectador.

As personagens são a metonímia da obra, pela sucessão de fatos que acontecem na cidade sem que as situações sejam explicadas, sendo sempre deixado um espaço em branco para a interpretação, o que induz ao espectador aproveitar estes silêncios para pensar em seus próprios medos. A ausência de trilha sonora contribui para o clima denso e dramático, com sons sempre diegéticos, com exceção da narração in off. Para Haneke, os diálogos têm de ser precisos e servir para confirmar o fato representado, e não como ocorre em alguns casos, em que se usam sons e músicas para disfarçar as possíveis carências de roteiro. É por meio da teatralidade, das tensões da imagem, dos planos-sequência, e desta série de recursos, que Haneke constrói uma crítica sobre as perversidades que existem no mundo e que fazem parte da vida das pessoas, deixando impressões não só na história, mas também nas consciências.

O uso do preto e branco na obra é essencial, pois o efeito monocromático causa maior impacto, retratando o espírito humano encontrado no filme. A perversão moral contamina a sua construção estética, fazendo com que o preto e o branco construam significados ambivalentes que permeiam todo o filme. 0 branco associa-se à pureza dos rostos, da neve que cobre a cidade no inverno e aos santificados campos de trigo que compõem um dos mais belos planos do filme, em contraste com as roupas negras que aprisionam o sujeito corrompível. É a partir da fotografia monocromática que o enunciador fílmico reforça a crueldade e a rigidez característica dos representantes da comunidade - que ganham destaque a partir da figura do médico, do pastor e do Barão -, bem como apresenta como se dão as relações estabelecidas entre estes e os demais habitantes. Nota-se, então, como as personagens agem diante das condições que lhe são dadas. Às vezes, elas tentam enfrentar as imposições, mas geralmente acabam vitimadas pelas crueldades e brutalidades da 
população local. Entre as vítimas encontram-se as mulheres - de diferentes faixas etárias -, que vivem nesta sociedade patriarcal ${ }^{3}$, protestante e rigorosa, sofrendo com as posições estabelecidas entre o feminino e o masculino.

Nos estudos culturais, a questão de gênero é discutida para - problematizar a formulação de que a biologia é o destino. A distinção entre sexo e gênero atende à tese que, por mais que o sexo pareça intratável em termos biológicos, o gênero é culturalmente construído. Conforme Butler (2010, p. 24), consequentemente, gênero não é resultado causal do sexo, nem aparentemente fixo quanto o sexo.

Se alguém "é" uma mulher, isso certamente não é tudo o que esse alguém é; o termo não logra ser exaustivo, não porque os traços predefinidos de gênero da "pessoa" transcendam a parafernália específica de seu gênero, mas porque o gênero nem sempre se constituiu de maneira coerente ou consistente nos diferentes contextos históricos, e porque o gênero estabelece intersecções com modalidades racistas, classistas, étnicas, sexuais e regionais de identidades discursivamente constituídas. (BUTLER, 2010, p. 24).

O termo "gênero" afirma que as relações entre os sexos são sociais, mas não diz como essas relações são construídas, como funcionam, portanto, se associa ao estudo das coisas relativas às mulheres. Para Scott (1990), as teorias do patriarcado explicam a subordinação das mulheres na "necessidade" do homem dominar as mulheres, o princípio da continuidade da geração através da reprodução. No entanto, as teorias do patriarcado não explicam o que a desigualdade de gênero tem a ver com outras desigualdades, baseia-se na diferença física, sem qualquer construção sociocultural e, portanto, a não historicidade do gênero. Por isso, é preciso dar atenção aos sistemas de significação e às maneiras como as sociedades e a comunicação representam o gênero, utilizando-as como forma de articular regras sociais ou construir sentido. A linguagem é uma das maneiras de construir a identidade de gênero, de fixá-la ou de subvertê-la.

Em uma das primeiras cenas do filme A Fita Branca (2009), o pastor está sentado à mesa aguardando a chegada dos filhos para o jantar - Martin e Klara, os filhos mais velhos, pedem desculpas ao pai pelo atraso e param em frente à porta.

Pastor: - Ninguém comeu nesta casa hoje. Como anoiteceu e vocês não chegavam, sua mãe saiu chorando para procurar vocês pela aldeia. Como

\footnotetext{
3 Nascida do estilo de vida das minorias dominantes, essa perspectiva acabou influenciando todas as outras camadas da sociedade - da produção e do consumo à política, à legislação e à cultura -, disseminando entre os homens um sentimento de posse sobre o corpo feminino e atrelando a honra masculina ao comportamento das mulheres sob sua tutela. Assim, cabia a eles disciplinar e controlar as mulheres da família, sendo legítimo, muitas vezes, o uso da força para isso. Prática que estrapolava as questões de autoridade, sendo passadas, muitas vezes, do pai para o marido. Os projetos individuais das mulheres, seus desejos e sentimentos particulares não tinham espaço, o que importava era o grupo familiar e nele a vontade do seu chefe, o patriarca.
} 
poderíamos comer em paz temendo uma desgraça? Como comer em paz agora, depois de ouvir essas desculpas mentirosas? Não sei o que foi pior: o sumiço de vocês ou o retorno. Vamos todos para a cama com fome. Sei que concordam que eu não posso deixar essa transgressão impune, se quisermos continuar vivendo com respeito mútuo. Por isso, amanhã neste horário, na frente dos seus irmãos vou açoitar 10 vezes cada um de vocês. Até lá, tratem de refletir sobre a gravidade do que fizeram. (A FITA BRANCA, 2009).

Na cena, todos concordam e, em silêncio, levantam da mesa: filhos e mãe. Os filhos menores pedem a bênção a ambos. 0 pai é apresentado sempre em primeiro plano e em close enquanto fala, já a mãe permanece em segundo plano sem falas durante a cena. Em relação aos filhos mais velhos, o patriarca fala:

\begin{abstract}
Pastor: - Não encostem em mim! A mãe de vocês e eu vamos dormir muito mal. Tenho que bater nos dois e isso vai doer mais em nós do que em vocês. Agora, podem ir para a cama. Quando eram pequenos, a mãe de vocês amarrava uma fita no cabelo ou no braço de vocês. Ela era branca para lembrar vocês da pureza e da inocência. Pensei que já tivessem virtude e retidão de sobra no coração para não precisarem mais desse tipo de lembrete. Eu estava enganado. Amanhã, após o castigo, vocês estarão purificados. A mãe de vocês irá amarrar a fita novamente e ficarão com ela até que possamos voltar a confiar nos dois. (A FITA BRANCA, 2009).
\end{abstract}

Nesta cena, a mulher está representada na condição de boa esposa, o que significa não falar, não questionar os argumentos do marido. É uma figura feminina que não consegue fugir das suas "obrigações" e não pode tomar decisões independentes.

No filme, a esposa do pastor não tem nome, ou seja, o seu nome não é mencionado em nenhum momento da obra. 0 que prepondera em sua atitude é o silêncio. A extensa fala, o sermão do pai, é dito em nome dele e em nome da mãe, sem importar se o dito remete à sua opinião, a fala do pai é dita também em nome dela e esta se mantém em sinal de respeito e obediência. Não há qualquer interferência nas decisões tomadas pelo marido, diante dos problemas familiares. Por exemplo, o filho caçula vai até o pai pedir para cuidar de um passarinho machucado, conforme pedido da mãe, já que essa decisão não pode ser tomada por ela.

Na cena seguinte, a mãe pega em sua caixa de costura a fita branca e corta uma a uma no mais completo silêncio, apaga a vela e chama os filhos mais velhos, Klara e Martin, encaminhando-os até a sala de jantar. Ela fecha a porta e a câmera não avança até as personagens, fazendo com que o espectador assista de longe o que se passa na cena. A entrada das crianças pela porta e a saída de um deles para buscar o chicote reforçam o conteúdo dramático. Cada vez que a porta é aberta, é a figura da mãe que está na sala à 
espera. Essa sequência offscreen pode causar um desconforto no espectador, que possivelmente fica angustiado no silêncio do filme prevendo o castigo às crianças.

Encontra-se nesta cena, assim como em toda a história, uma incompletude, deixando diversas incertezas para serem interpretadas pelo espectador. Conforme Umberto Eco (1986), uma narrativa está entremeada de espaços em branco, de interstícios a serem preenchidos. Para Eco, há duas razões para que o emitente deixe esses espaços em branco: primeiro, porque o texto é um mecanismo preguiçoso que vive da valorização dos sentidos que o destinatário introduziu, e segundo, porque o texto quer deixar ao leitor a iniciativa interpretativa, embora costume ser interpretado com uma margem suficiente de univocidade. "Todo o texto quer que alguém o ajude a funcionar". (ECO, 1986, p. 37).

O silêncio da mãe em ambas as cenas pode possuir significados múltiplos. 0 pastor/marido em sua posição autoritária frente à sociedade e à família, se utiliza do discurso religioso de bons costumes e punição para estabelecer o seu lugar e o lugar do outro, no caso, da esposa. Ele toma a palavra da esposa em uma dimensão política, sendo o silêncio dela considerado parte da retórica do oprimido, enquanto ele se utiliza da retórica da dominação (opressão); manifesta-se o silêncio da disciplina, da domesticação. "O silêncio é fundante, quer dizer, o silêncio é a matéria significante por excelência. 0 real da significação é o silêncio". (ORLANDI, 2007, p. 29).

O silêncio não fala, ele significa. No entanto, é possível encontrar a fala da mãe por meio da gestualidade, das expressões de respeito e da afirmação. "Quando alguém se pega em silêncio, rearranja-se, muda a "expressão", procura ter uma expressão de fala". (ORLANDI, 2007, p. 34). 0 fato de produzir signos visíveis (audíveis) o tempo todo traz uma ilusão de controle em relação ao que está posto. Ao fazer uma análise, neste âmbito, é a partir de monólogos, como os apresentados no filme, que o marido mantém uma relação de poder perante a esposa.

0 médico da aldeia, após sofrer grave acidente, retorna do hospital para casa e a filha Anni o recebe sorrindo, feliz pelo seu retorno. Ela é quem o socorre quando acontece o acidente. Fora da casa, o médico fuma o seu cigarro enquanto a menina para ao seu lado, séria, no aguardo de atenção.

Anni: - Seu consultório está pronto. A Sra. Wagner arrumou tudo.

Pai: - Por que está me dizendo isto?

A: - Não sei. Pensei que fosse gostar de saber.

P: - Ela cuidou bem de vocês? Com quantos anos você está?

A: - Catorze. 
P: - É impressionante... você está a cara da sua mãe! (A FITA BRANCA, 2009).

Na cena seguinte, o irmão caçula de Anni acorda à noite e não encontra a irmã no quarto, ele desce as escadas a sua procura: percorre a casa e vê a luz no consultório do pai. 0 irmão abre a porta e vê Anni sentada sobre a maca abaixando a saia e o pai a sua frente cobrindo Anni:

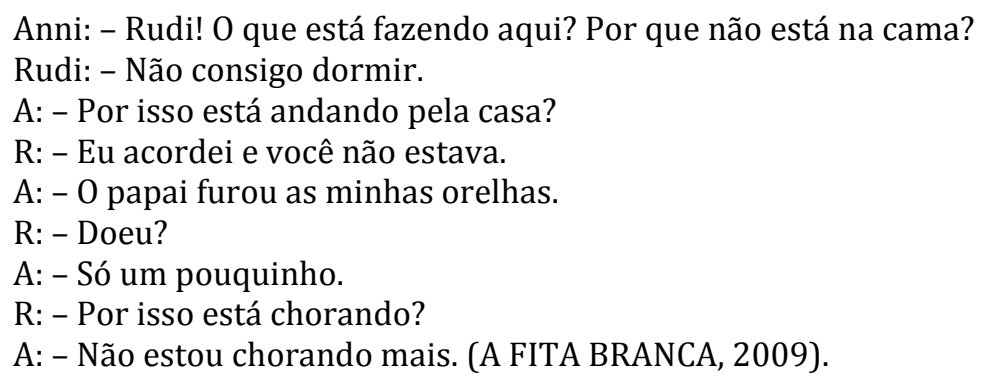

A segunda cena é montada para que o espectador deduza a ocorrência de um estupro, deixando claro o fato de que Anni é molestada pelo pai, mostrando a sua angústia através de um diálogo que vela a brutalidade do adulto. Anni sofre com o acidente do pai e no seu retorno sofre com sua atitude de indiferença e desprezo. Esse mesmo pai que a rejeita como filha, a deseja como mulher.

Neste discurso narrativo em que o pai molesta a filha, os fatos não são mostrados explicitamente, a ação não é nomeada; é subentendida através dos gestos de encobrir, esconder para não quebrar o decoro da representação. A questão de “[...] representar ou não representar assume feição diferente, conforme consideramos a narração sumária ou a cena - sempre será mais aceitável a referência mais geral, sem detalhes, daquilo que está sujeito aos tabus de caráter moral e que afeta o corpo". (XAVIER, 2003, p. 74).

Os corpos das mulheres são castos na imagem do filme, tratados com a distância necessária para garantir a existência apenas como signos, nunca como presenças reais.

Cenas com outra personagem trazem a mesma brutalidade relacionada ao médico, no entanto, além de mostrar corpos abusados, há agressões verbais. A Sra. Wagner, 40 anos, é parteira e assistente do médico, sendo também sua governanta desde a morte de sua esposa. Assim como Anni, ela veste roupas negras e usa um coque, símbolo de recato.

A primeira cena da Sra. Wagner com o médico não a mostra inicialmente, apresenta apenas o médico, de costas e vestido. Ele aparece em frente a um armário onde está a foto da falecida esposa e da família, insinuando-se o ato da relação sexual. Em seguida, vira-se a Sra. 
Wagner que tenta abraçá-lo. Ele reclama, não quer que ela o toque. Também vestida, ela o ajuda a recompor-se. Ambos sentam à mesa e bebem um cálice de vinho.

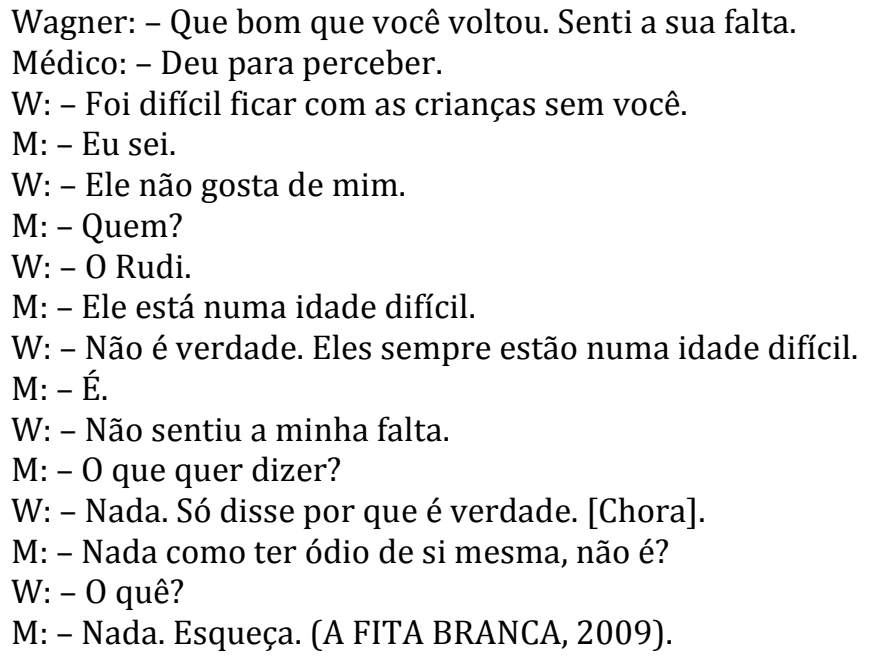

Após o diálogo, ela deita a cabeça na mesa em movimento de extrema submissão e carência à espera de um afago. A imagem mostra a mão sobre sua cabeça, sem movimento, o que permite a interpretação do sentimento de pena e misericórdia, ao invés de afeto. Na cena seguinte, em que os dois aparecem, a Sra. Wagner está masturbando o médico.

Médico: - Por que não para com isso? Para que tanto esforço? E não faça essa cara de espanto. Você até que é boa nisso, mas eu não suporto mais. Para ser sincero tenho nojo de você. Dá para terminar o seu trabalho? Não quero passar a noite aqui.

Wagner: - 0 que foi que eu fiz?

M: - Ai, meu Deus! Você não fez nada. Você é feia, desajeitada, flácida e tem mau hálito. Acha pouco? Essa tampa precisa ser esterilizada. Não fique aí sentada com essa cara de sofredora. 0 mundo não vai desabar sobre a sua cabeça. Nem sobre a minha. Eu não quero mais, só isso. Eu bem que tentei pensar em outra mulher quando fazia sexo com você. Uma mulher cheirosa, jovem, menos acabada que você, mas não tenho tanta imaginação assim. Mas no final, via você ali e tinha vontade de vomitar. Eu sentia vergonha de mim mesmo. Então, fazer o quê?

W: - Acabou?

M: - Sim, faz muito tempo.

W: - Deve estar muito infeliz para ter tanto rancor.

M: - Não comece com isso!

W: - Eu sei que não sou bonita. Tenho mau hálito por causa da minha úlcera, você sabe disso. Mas antes isso não incomodava você. Eu já era assim quando sua mulher era viva.

M: - Me poupe desses detalhes sórdidos. Fique sabendo que sempre tive nojo. Eu queria aliviar meu sofrimento depois da morte da Julie com quem quer que fosse. Podia ser até com uma vaca. As putas ficam longe daqui e uma vez a cada dois meses é pouco para mim, apesar da minha idade. Agora pare de dar uma de mártir e dê o fora.

$[\cdots]$ 
W: - Por que você me despreza? É porque ajudei a criar o menino? É porque vejo você bolinar a sua filha e não falo nada? É porque ajudo você a continuar se enganando, ouvindo você dizer o quanto amava a Julie, quando todos sabiam que a maltratava como faz comigo? É porque amo você sabendo que você não suporta ser amado?

M: - Exatamente. Agora levante que eu preciso trabalhar.

W: - Você não vai conseguir se livrar de mim. Quem vai fazer o seu trabalho sujo, cuidar das crianças e do consultório? Você está falando sem pensar. Você quer ver até onde posso chegar? Será que ela aguenta? Posso pisar mais forte? Também estou cansada. Cuido de duas crianças retardadas: o Karli e você. Você é o pior.

M: - Meu Deus! Por que você não cai morta? (A FITA BRANCA, 2009).

Nesta cena, a primeira parte do diálogo é filmada com a Sra. Wagner em primeiro plano, sentada no mesmo local e com uma expressão de mágoa em relação ao que ouvira. Na sequência, a cena contrapõe a imagem dela com a do médico, que permanece de costas olhando a rua pela janela. Neste momento, o diálogo pesado e pessimista ressalta as características de uma mulher instruída a viver para o homem e não para si, subordinada à crueldade e à estrutura patriarcal. Em ambas as relações do médico, tanto com a filha Anni, quanto com a Sra. Wagner, é possível reconhecer uma articulação ambivalente e contraditória de fetiche, sendo elas um objeto de desejo e escárnio do homem, uma articulação da diferença contida dentro da fantasia da origem da identidade.

De acordo com Bhabha (1998), o fetiche dá acesso a uma "identidade" baseada em uma relação de dualidade, tanto na dominação e no prazer, quanto na ansiedade e na defesa, pois é uma forma de crença múltipla e contraditória em seu reconhecimento da diferença e da recusa de tal relacionamento. É um conflito entre prazer/desprazer, dominação/defesa, conhecimento/recusa, ausência/presença. 0 médico as despreza, mas também as deseja e vice-versa. É uma relação dialética entre os sujeitos (eu/outro - homem/mulher autoridade/subserviência), colocados sempre em oposição ou dominação através do descentramento simbólico de múltiplas relações de poder. A cultura está em um espaço entre este binarismo.

No autoritarismo, não há reversibilidade possível no discurso, isto é, o sujeito não pode ocupar diferentes posições: ele só pode ocupar o "lugar" que lhe é destinado para produzir os sentidos que não lhe são proibidos. A censura afeta, de imediato, a identidade do sujeito. Nesse passo podemos fazer uma relação entre a rarefação do sentido produzida pela relação com o poder, e a produzida pela relação com o desejo. (ORLANDI, 2007, p. 79).

Ao final do diálogo, em meio ao seu breve desabafo seguido da não aceitação da recusa, a Sra. Wagner relata todos os não ditos de sua vida ao lado do médico e todos os discursos do médico que silenciaram aspectos cruciais de suas vidas - forma de 
domesticação, o discurso de amor à esposa falecida com a intenção de estabilizar a memória de toda a família. No entanto, em relação ao Karli, filho da parteira, permanece o silêncio.

Outra personagem feminina que possui evidência no filme é Klara, a filha do pastor. No decorrer da trama, as histórias das famílias são permeadas por incidentes trágicos e pela presença constante das crianças em lugares-chave, onde ocorreram os incidentes e, após, em contato com as famílias oferecendo-lhes ajuda. No centro deste grupo, há a presença constante de Klara, que sempre está com as demais crianças no seu entorno. Klara é uma das filhas mais velhas do pastor, o qual cultiva o hábito de amarrar fitas brancas nos cabelos ou nos braços dos filhos como forma de lembrá-los da importância da pureza e da inocência, bem como da sua condição de pecadores - uma marca simbólica que representa a visão limitada do pai/pastor, que condena a sexualidade e sufoca todo e qualquer instinto vital, tendo a violência em casa como um remédio civilizador, cujos efeitos trazem ainda mais violência.

Em uma das cenas, o pai retira a sua fita branca e devolve após tê-la açoitado. $\mathrm{Na}$ sequência há a cena da escola em que todas as crianças estão na sala de aula aos gritos, divertindo-se, enquanto Klara fica na porta em silêncio. Quando ela vê o pai/pastor atravessar a rua, ela corre para dentro da sala e grita para que todos fiquem quietos. 0 pastor e o professor entram no recinto e todos paralisam. 0 pai/pastor pega Klara pelas orelhas e a coloca de costas no fundo da sala. 0 professor pergunta o que ainda estão fazendo no local e diz que está na hora da aula de catecismo pedindo que todos saiam. 0 pastor reza o Pai Nosso junto às crianças e todos se mantêm em silêncio.

Pastor: - Hoje é um dia muito triste pra mim. Em poucos dias, todos nós iremos celebrar a Crisma de vocês. Durante meses venho tentando aproximá-los do mundo de Deus e transformar vocês em seres humanos responsáveis. E o que encontro aqui hoje? Um bando de macacos berrando!. [...]. Mas para mim o que é mais triste é ver minha filha protagonizando esse espetáculo deplorável. No ano passado eu amarrei uma fita branca no cabelo dela. 0 branco como bem sabem é a cor da inocência. A fita deveria ajudar Klara a evitar o pecado, o egoísmo, a inveja, a indecência, a mentira e a preguiça. No começo deste ano acreditei, ingenuamente, que ela estivesse madura o suficiente para não usar mais a fita. (A FITA BRANCA, 2009).

Após o discurso do pai, Klara desmaia ao fundo da sala, febril e enfraquecida. Em nova cena, Klara entra no escritório do pai e vasculha as gavetas à procura de uma tesoura, ao encontrar, abre a gaiola onde está o passarinho de estimação do pai e o pega. Ao chegar em casa, o pai encontra o pássaro morto sobre a sua mesa. A disciplina do pai em relação aos filhos é tão autoritária que além de medo gera o sentimento de vingança, podendo 
manifestar-se das mais diferentes formas. À Klara, assim como aos demais filhos, não se permite a individualidade de expressão e autonomia de conduta.

O uso incessante da religião pelo pai castrador é uma forma de dar à filha uma visão já estabelecida das coisas. Esse controle lhe faz acreditar que a está resguardando de tudo o que pode parecer uma ameaça, o que se torna contraditório a partir do ato da filha. Longe dos olhos da religião, há uma moral hipócrita: uma distinção entre a rua e a casa, entre o visível e o espaço íntimo da família.

A fita branca usada pela menina tem a cor como forma de diferenciação, sinônimo de pureza. A educação rigorosa e a religião também se apresentam à filha como forma de princípios austeros fundamentais. No entanto, os interditos protestantes alimentam uma prática de repressão dos desejos levando-a ao exercício da insurgência vingativa. 0 mal e a pureza de Klara se apresentam como reflexo e refração um do outro.

Conforme Cassirer (2006), as formações verbais, a palavra, são vistas como formas que possuem uma função determinada, para as quais são conferidos determinados poderes míticos, convertendo-se numa espécie de arquipotência, onde radica todo o ser e todo acontecer. "A palavra é elevada à esfera do religioso, à esfera do sagrado. [...]. Deus usou a palavra como meio de expressão e como instrumento de criação". (CASSIRER, 2006, p. 65). 0 autor acrescenta: "Tudo o que é, chega ao ser através do pensamento de seu coração e o mandamento de sua língua". (CASSIRER, 2006, p. 65). Desta forma, através do uso da palavra, é reportada ao pai a representação de um "Salvador", como se ele se convertesse no próprio ideal de salvação.

A especificidade do discurso de autoridade (aula, sermão, etc.) reside no fato de que sua compreensão não é suficiente, e de que a efetivação de seu efeito específico depende de ele ser reconhecido como tal. Esse reconhecimento só acontece, uma vez que é evidente, sob certas condições, as que definem o uso legítimo. (BOURDIEU, $1982^{4}$ apud AMOSSY, 2011, p. 121).

Desta forma, sendo compreendido ou não, o pai/pastor, através do uso da palavra se mantém no poder, e este poder frente aos olhos da filha chega ao extremo medo, fazendo com que a menina ficasse doente pelo destrato.

Na última cena da seleção apresentada, há uma surpresa. Durante todo o filme ve-se os entraves que dificultam a luta da mulher pelo que deseja. Geralmente, quando tentam mudar o enquadramento a que são submetidas, acabam sendo agredidas de alguma forma.

${ }^{4}$ BOURDIEU, P. Ce que parler veut dire: l'economie des échanges linguistiques.Paris: Fayard, 1982. 
Em uma das cenas finais do filme, a baronesa revela ao seu marido não apenas um desejo, mas uma decisão tomada independente da sua opinião, revelando a sua insatisfação em relação ao casamento e à vida na aldeia.

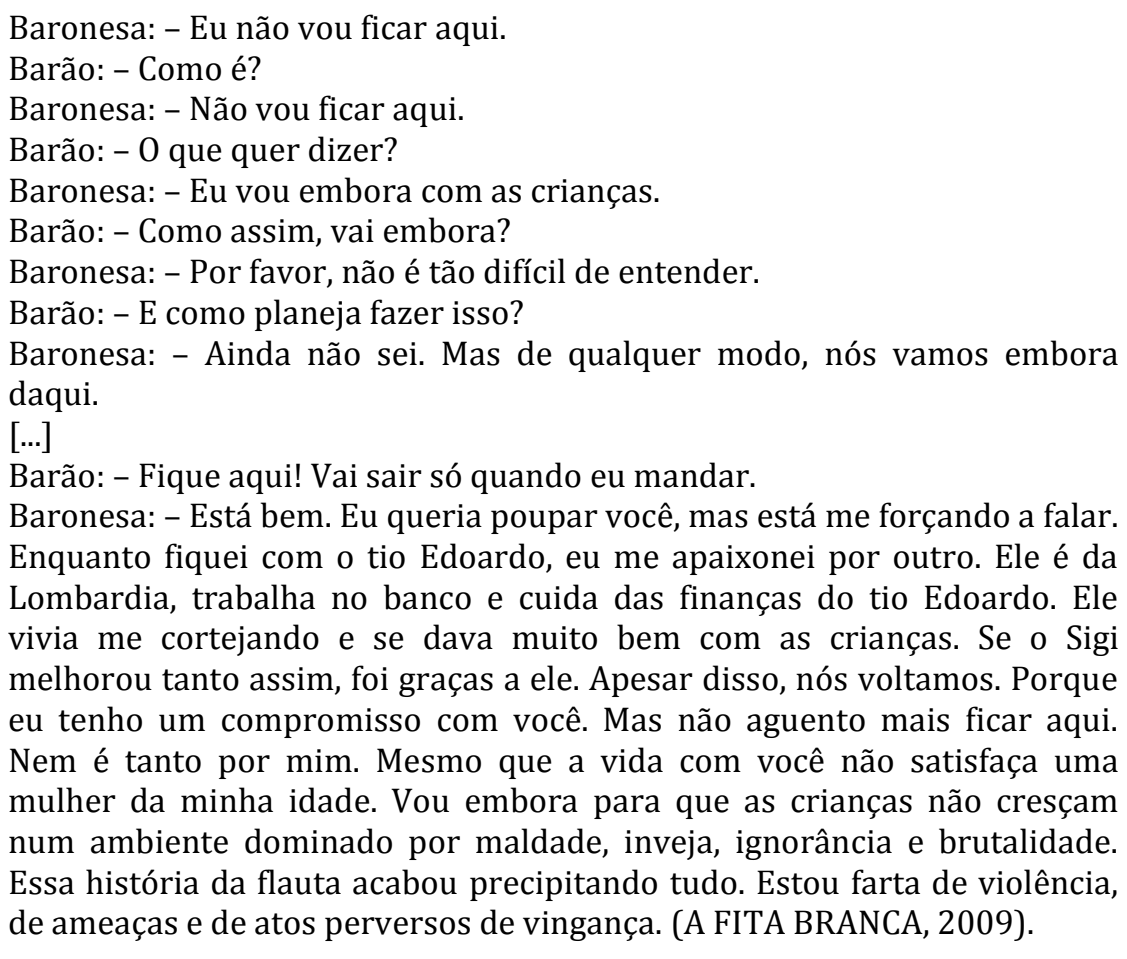

A revelação é surpreendente para o barão e possivelmente para alguns espectadores, que talvez não esperassem em tal situação uma quebra das leis conjugais estabelecidas pela igreja. A narrativa demonstra a permanência dos desejos e dos sonhos das mulheres mesmo com as condições impostas. A surpresa é maior quando não há qualquer violência física dirigida a ela, que apesar da coragem, ainda demonstra receio e preocupação diante do marido. Todas essas mulheres têm o que dizer, o que é demonstrado no último diálogo da Sra. Wagner e no diálogo da baronesa. Elas expressam a fragmentação de suas identidades, as quais foram abafadas pelo discurso patriarcal de ordem e da sociedade em que vivem.

\section{Considerações finais}

No decorrer da obra foram identificadas diferentes representações femininas relacionadas às principais personagens. A esposa do pastor é apresentada como a boa mãe e esposa exemplar, sem possibilidade de fala, sem autonomia e poder de decisão perante a família. Ela está sempre expressando a obediência mantida em relação ao marido através dos gestos. A parteira, Sra. Wagner, é um exemplo de criada, sendo a ela atribuídas as mais 
diferentes funções: cuidar dos filhos do médico, cuidar da casa, do escritório, sendo governanta, parteira e assistente do médico. Além de suas atividades, há a "função" de amante, já que tal relação é vista pelo médico como uma prestação de serviço. Sra. Wagner é a representação da boa empregada e subserviente amante.

Anni, a filha do médico é representada como a boa irmã, aquela que assume o papel da mãe na criação do irmão, dando afeto e explicando questões sobre a vida. No entanto, assume ainda o papel da mãe ao se preocupar com o pai, mesmo sofrendo abusos do mesmo. A jovem é reprimida e dominada pela autoridade paterna. Klara, a filha do pastor também é contida pelo pai, mas, além do domínio patriarcal, isso ocorre sob o aspecto religioso. Ela é mostrada como o símbolo da pureza e da inocência a partir da fixação paterna por estas representações, o exemplo de boa filha. Em contradição, a obra também a mostra como representação da vingança e da maldade, ao passo que a menina assume de forma implícita a figura de líder do grupo de crianças que percorre a aldeia fazendo atrocidades.

No final, o filme retrata a baronesa e a sua insatisfação em relação à vida. Uma mulher instruída que decide lutar pela própria felicidade e que, mesmo quando vetada pelo marido e respeitando as suas ordens, parece não desistir da decisão de deixá-lo.

O inusitado vem pelo fato de que todas estas representações construídas através de discursos, silêncios e de sistemas simbólicos constituem a identidade do sujeito, posicionando estas mulheres em lugares marcados, fixados, de onde, aparentemente, não podem mover-se. Na obra, a sociedade e o homem dizem quem é a mulher, quem ela deve ser, sua posição-sujeito ocupada pela boa mãe, boa empregada, boa amante, boa irmã e boa filha.

A identidade ainda hoje é construída por espaços marcados e partir da linguagem, da cultura e de resquícios de representações históricas que afetam a forma como podemos representar a nós mesmos. Hall (2012) afirma que as nossas identidades parecem invocar uma origem que reside em um passado histórico com o qual elas continuariam a manter certa correspondência.

Em A Fita Branca, a identidade das mulheres constituiu-se no interior de práticas discursivas e no interior do jogo de modalidades específicas de poder. Uma identidade unificada, sem costuras e sem diferenciação interna. Este não é um modelo natural, mas é o modelo em que a mulher assume como fundacional na obra, já que todas possuem representações semelhantes. 
O filme retrata uma época em que as mulheres eram extremamente subordinadas e inferiorizadas pelos homens, sem reação em detrimento destes fatos. 0 desconforto por parte do espectador em relação aos fatos apresentados talvez se manifeste não só por discordância ao que se vê, mas talvez por perceber como são completamente prescindíveis as dicotomias estabelecidas nas relações entre homens e mulheres, pois a obra consegue explicitar situações que, mesmo minimizadas nos dias de hoje, permanecem. Somos atingidos pelas tragédias, crueldades e intolerâncias da história que não escapam de algumas ideologias sociais ainda existentes.

Por fim, como Chartier (1990) salientou, existe uma luta forte, simbólica e crucial pelo poder, que passa pelo controle do indivíduo e da sociedade, revigorando a ideia de que onde existe o indivíduo e a sociedade, está presente a representação. Cabe por fim, refletir sobre a condição humana e a tênue linha que nos separa da barbárie e da crueldade dentro dos limites sociais. Apesar dos avanços do século XXI, a condição frente a qual as mulheres estão sujeitas tende a ressurgir em diversas proporções. Sob uma nova configuração, as fitas brancas permanecem amarradas à identidade de muitas mulheres ainda hoje, aceitando o silêncio em nome de um sustento social.

\section{Referências}

A FITA BRANCA. Direção e roteiro de Michael Haneke. Áustria, 2009. Título original: Das Weisse Band/Eine Deutsche Kindergeschichte. Produção: Michael Katz. Intérpretes: Burghart Klaußner, Christian Friedel, Ernst Jacobi, Josef Bierbichler, Leonie Benesch, Steffi Kühnert, Ulrich Tukur, Ursina Lardi. Roteiro: Michael Haneke. Fotografia: Christian Berger. São Paulo: IMOVISION, 2009. 1 DVD (144 min.).

AMOSSY, Ruth. $O$ ethos na intersecção das disciplinas: retórica, pragmática, sociologia dos campos. In: (Org.). Imagens de Si no Discurso: a construção do ethos. São Paulo: Contexto, 2011. p. 119-144.

BAKHTIN, Mikhael. Marxismo e Filosofia da Linguagem. São Paulo: Hucitec, 2004.

BHABHA, Homi. O Local da Cultura. Belo Horizonte: UFMG, 1998.

BUTLER, Judith. Problemas de Gênero: feminismo e subversão da identidade. 3. ed. Rio de Janeiro: Civilização Brasileira, 2010.

CASSIRER, Ernst. Linguagem e Mito. São Paulo: Perspectiva, 2006.

CHARTIER, Roger. A História Cultural: entre práticas e representações. Rio de Janeiro: Bertrand Brasil, 1990. 
ECO, Umberto. 0 leitor-modelo. In: ECO, Umberto. Lector in fabula. São Paulo: Perspectiva, 1986. p. 35-49.

GAUDREAULT, André; JOST, François. A Narrativa Cinematográfica. Brasília: UNB, 2009.

HALL, Stuart. Identidade Cultural na Pós-Modernidade. Rio de Janeiro: DP\&A, 1999.

HALL, Stuart. Quem precisa da Identidade? In: SILVA, Tomaz Tadeu da (Org.). Identidade e diferença: a perspectiva dos estudos culturais. Petrópolis: Vozes, 2012. p. 103-133.

ORLANDI, Eni Puccinelli. As Formas do Silêncio. 6. ed. Campinas: Unicamp, 2007.

SCOTT, Joan W. Gênero: uma categoria útil de análise histórica. Educação e Realidade, Porto Alegre, v. 16, n. 2, p. 71-99, jul./dez. 1990.

SILVA, Tomaz Tadeu da (Org.). Identidade e diferença: a perspectiva dos estudos culturais. Petrópolis: Vozes, 2012.

XAVIER, Ismael. Do Texto ao Filme: a trama, a cena e a construção do olhar no cinema. In: PELLEGRINI, Tânia (et al.). Literatura, Cinema e Televisão. São Paulo: SENAC, 2003. p. 6189.

WOODWARD, Kathryn. Identidade e Diferença: uma introdução teórica e conceitual. In: SILVA, Tomaz Tadeu da (Org.). Identidade e Diferença: a perspectiva dos estudos culturais. Petrópolis, RJ: Vozes, 2012. p. 7-72.

\title{
Identity and representation: film review focused at woman in the White Band movie
}

\begin{abstract}
The present article analyses the feminine representation on the German movie "The White Band" (2009), beyond the way in which these representations constitute the women's identity. Through the description of both scenes and sequences of the movie, as well as the incorporation of the concepts of representation, identity and discourse, we aim on showing the manner in which women are subjugated, besides all severity, patriarchalism and puritanism of the local society.
\end{abstract}

\section{Keywords}

Woman. Representation. Identity. Film analysis 
Identidad y representación: análisis de cine de la mujer em La Cinta Branca

\section{Resumen}

En este artículo se analizan las representaciones femeninas existentes en la película alemana La Cinta Blanca (2009), además de cómo estas representaciones constituyen la identidad de las mujeres en la película. A través de la descripción de escenas y secuencias y la incorporación de los conceptos de representación, identidad y discurso busca demonstrar cómo las mujeres son dominadas, más allá de toda rigidez, el patriarcado y el puritanismo de la sociedad local.

\section{Palabras-clave}

Mujeres. Representación. Identidad. Análisis de cine.

Recebido em 24/03/2014

Aceito em 04/03/2015 